\title{
Efektivitas Acceptance Commitment Therapy Dalam Meningkatkan Subjective Well Being Pada Dewasa Muda Pasca Putusnya Hubungan Pacaran
}

\author{
SRI JUWITA KUSUMAWARDHANI ${ }^{1}$, E. KRISTI POERWANDARI ${ }^{2}$ \\ ${ }^{1}$ Fakultas Psikologi, Universitas Pancasila, ${ }^{2}$ Fakultas Psikologi, Universitas Indonesia \\ Email: sjkusumawardhani@gmail.com
}

\begin{abstract}
Romantic relationship is one of the most important assets for individual's self esteem, health and happiness or their subjective well-being (Reis, Collins, \& Berscheid, 2000). By that fact, the brokeup of the romantic relationship can decrease the level of happiness and subjective well-being of individuals whether the subjective well-being itself is relatively stable for the entire life (Park \& Sanchez, 2007). Sometimes an individual responded their broke-up by doing some maladaptive acts such as an endless emotional distress and obsessive act just to get back their ex-partner. The purpose of this research is to give Acceptance Commitment Therapy (ACT) in order to enhance people's happiness. The research design is using one group pretest-postest design. As a partisipant, young adult should be in 20 until 40 years of age. This intervention contains 5 (five) session which held once in a week and the duration is \pm 90 minutes per session. Based on the quantitative evaluation with Oxford Happiness Questionnaire and Core Bereavement Item, and also the qualitative evaluation from observation and interview, the main result pointed that Acceptance Commitment Therapy is effectively proven to increase subjective well-being in Young Adults' post relationship dissolution.
\end{abstract}

Keywords : Subjective well-being, Emotional Distress, Acceptance Commitment Therapy, Young Adulthood, Post Relationship Dissolution

\section{PENDAHULUAN}

Hubungan romantis dianggap mampu memenuhi kebutuhan manusia yang paling fundamental yakni the need to belong atau kebutuhan untuk memiliki. Berscheid dan Reis (1998) pun menambahkan bahwa hubungan romantis menjadi sumber subjective well being atau kebahagiaan dan kepuasan yang penting bagi mayoritas orang. Hubungan romantis yang dilandasi oleh cinta merupakan kekuatan dasar pada masa dewasa muda, oleh karena itu para individu dengan rentang usia 20 hingga 40 tahun akan berusaha untuk menjalin keintiman agar mampu melewati krisis (Erikson dalam Feist \& Feist, 2009). Kualitas dari hubungan dengan pasangan menjadi penting terutama pada remaja dan dewasa muda untuk meningkatkan subjective well being. Cinta dan kepuasan dalam hubungan romantis menjadi prediktor penting atas kebahagiaan, kesejahteraan, dan emosi positif lainnya (Theuns dkk, 2010)

Konsep putusnya hubungan romantis dianggap serupa dengan konsep bereavement atau berduka karena kedua peristiwa tersebut melibatkan perasaan kehilangan atas orang terkasih (Docherty, 2007). Dalam proses berduka yang tergolong sehat, individu secara bertahap mampu menyadari dan menerima proses putusnya suatu hubungan sebagai sesuatu yang permanen dan serta mulai untuk melakukan redefinisi status dirinya sesuai dengan situasinya saat ini (Van IJzendoorn \& Bakermans-Kranenburg, 1997). Di sisi lain, individu dengan kemampuan adaptasi yang buruk terhadap putusnya hubungan pacaran 
akan jauh lebih banyak merasakan kesedihan dan menunjukkan cinta secara persisten terhadap mantan pasangannya atau dengan kata lain hal tersebut dikarakteristikkan sebagai kegagalan untuk menyelesaikan sumber dari grief yang mereka rasakan. Putusnya hubungan romantis secara empiris telah diasosiasikan dengan beragam respon fisik dan emosional yang negatif, mulai dari kecemasan, depresi, psikopatologi, kesepian, daya tahan tubuh yang menurun, sakit fisik baik secara fatal dan non fatal, serta menurunnya kuantitas hidup hingga kematian mendadak melalui proses bunuh diri (Kiecolt-Glaser \& Newton, 2001). Selain distres psikologis, dampak lainnya dari putus hubungan pacaran adanya kemunculan relationship pursuit atau perilaku obsesif dalam mengejar mantan pasangan. Perilaku tersebut terjadi akibat salah satu pihak dari putusnya hubungan pacaran mengalami ruminasi terhadap mantan pasangannya sehingga mereka berusaha untuk terus mengejar mantannya tersebut (Cupach, 2003).

Pihak yang diputuskan melaporkan pengalaman depresi yang lebih banyak disertai dengan ruminasi yang lebih sering, ditambah dengan pengurangan self esteem, serta mempersepsikan diri sebagai individu yang kurang diinginkan, dan merasa lebih khawatir bahwa mereka akan kesulitan untuk menemukan pasangan yang baru (Periloux \& Buss, 2008). Terkait dengan perbedaan gender, para wanita lebih ekspresif secara emosional dan sensitif dibandingkan para lelaki terhadap peristiwa emosional (Honeycutt \& Cantrill, 2000). Oleh karena itu, para wanita lebih terpengaruhi kebahagiaan dan kesejahteraannya sehingga mereka melaporkan depresi jauh lebih banyak dibandingkan lelaki setelah putus hubungan. Terkait dengan distres psikologis, Nolen-Hoeksema \& Girgus (1994) menyatakan bahwa perempuan menderita simptom depresi lebih banyak dibandingkan laki-laki setelah mengalami hubungan putus pacaran. Hal tersebut didukung oleh Mearns (1991) yang menyatakan bahwa perempuan jauh lebih dependen dan kurang asertif sehingga mereka lebih mudah merasa depresi setelah putus dengan pasangannya.

Seperti yang dipaparkan diatas, individu yang mengalami putusnya hubungan pacaran mengalami banyak dampak negatif dari peristiwa tersebut sehingga membuatnya sulit dalam melakukan penerimaan yang menyebabkan terjadinya penurunan tingkat subjective well being atau kebahagiaan dalam hidup mereka (Torges \& Nolen-Hoeksema, 2008). Istilah Subjective well being sering disebut pula sebagai kebahagiaan didefinisikan sebagai keadaan psikologi positif yang ditandai dengan adanya emosi pengalaman menyenangkan atau afek positif, rendahnya tingkat afek negatif, dan derajat kepuasan hidup yang tinggi (Carr, 2004). Subjective well being kerap dinilai sangat penting karena berkaitan erat dengan kondisi-kondisi positif yang membantu seseorang menjalankan fungsinya secara optimal. Subjective well being dipercaya dapat membuat seseorang mencapai kesehatan mental, kesehatan fisik, serta memiliki kemampuan coping yang lebih baik, dan hidup yang lebih panjang (Sheldon, 2005). Selama ini, penelitian mengenai kebahagiaan atau subjective well being yang dilakukan lebih banyak berfokus pada keadaan negatif dibandingkan positif. Penelitian dan intervensi 
terhadap kesehatan mental masih banyak berkisar pada cara mengurangi penderitaan, kelemahan, rasa cemas, dibandingkan meningkatkan kebahagiaan dan kesejahteraan (Lyubormrsky \& Sheldon, 2005).

Lebih lanjut, Sheldon menjelaskan bahwa ketika intervensi dilakukan untuk mengurangi keadaan negatif maka tingkat kesejahteraan mereka kembali nol bukannya membantu mereka mencapai kebahagiaan yang optimal. Oleh karena itu, penting rasanya untuk membantu seseorang meningkatkan level kebahagiaan dan kesehatan mental yang positif. Salah satu teknik intervensi yang dipercaya dapat meningkatkan kebahagiaan seseorang adalah Acceptance Commitment Therapy (ACT) (Harris, 2008). Oleh karena itu, studi ini bertujuan untuk meningkatkan tingkat subjective well being para individu dewasa muda pasca putusnya hubungan pacaran mengingat dampak negatif yang muncul seperti depresi hingga percobaan bunuh diri tentunya mengganggu keberfungsian mereka dalam menjalani kehidupan sehari-hari.

Acceptance commitment therapy (ACT) bertujuan untuk menghasilkan kehidupan yang bermakna dengan melakukan penerimaan terhadap rasa sakit yang tidak dapat dihindari (Harris, 2006). ACT yang mampu untuk meningkatkan fleksibilitas psikologis seseorang menganggap bahwa usaha menghindari suatu pengalaman atau permasalahan akan membuat seseorang semakin terjebak dalam hal tersebut hingga menimbulkan distres dan penurunan subjective well being (Fledderus, 2012). Oleh karena itu, ACT dianggap sebagai terapi yang sesuai untuk menyelesaikan permasalahan depresi dan meningkatkan kesehatan mental karena ACT membuat seseorang mampu menerima setiap pengalaman dan peristiwa yang telah terjadi dan kembali berfungsi dengan normal dalam menjalani kehidupan sehari-hari sesuai dengan value dan tujuan hidupnya (Hayes, 2010).

Pada umumnya, individu datang ke terapi untuk melakukan kontrol emosional. Mereka ingin menghilangkan perasaan depresi, kecemasan, memori traumatik, ketakutan akan penolakan, perasaan marah, berduka, dan lainlain. Akan tetapi, di dalam penerapan ACT tidak ada usaha percobaan untuk mengurangi, mengubah, menghindari atau mengontrol pengalaman pribadi (Harris, 2006). Melalui teknik ini, individu belajar untuk menghilangkan dampak dan pengaruh dari pikiran serta perasaan yang tidak diharapkan melalui penggunaan mindfulness secara efektif. Jika sebelumnya mereka membuang waktu, energi, dan uang mereka dengan sia-sia untuk mengontrol emosi mereka dengan teknik ini energi mereka disalurkan untuk proses pengambilan tindakan efektif agar hidup mereka menjadi lebih baik dan bermakna (Harris, 2006).

ACT memiliki enam prinsip utama yakni acceptance, cognitive defusion, mindfulness, observing self, value, dan commitment. Acceptance adalah proses untuk meningkatkan penerimaan secara menyeluruh terhadap pengalaman subjektif, meliputi pemikiran, kepercayaan, sensasi, dan perasaan yang menimbulkan distres, sebagai usaha untuk meningkatkan perubahan perilaku yang diinginkan sehingga mengarah pada meningkatnya kualitas hidup (Forman dkk, 2005). Sedangkan prinsip cognitive defusion 
bermakna sebagai proses untuk dapat mengamati pemikiran sehingga dampak dan pengaruhnya menjadi lebih sedikit dibanding ketika kita mengalami fusion dengan pemikiran kita (Harris, 2006).

Prinisip ketiga adalah mindfulness, Individu diharapkan agar mampu memberikan fokus dan terlibat penuh terhadap apa yang ia lakukan di masa kini (Harris, 2006). Kemudian, prinsip observing self memungkinkan individu untuk mengalami langsung bahwa dirinya bukan hanya sekedar pikirannya, emosinya, perannya, sensasi tubuhnya, dan dorongannya. Semua aspek tersebut dapat berubah secara konstan sehingga dianggap sebagai bagian dari pengalaman bukan keyakinan dan esensi dari seorang individu (Forman dkk, 2005). Prinsip kelima adalah Value. Prinsip ini bertujuan untuk mengklarifikasi apa yang paling penting bagi seorang individu di dalam hidupnya, ingin menjadi seperti apa dia di dalam hidupnya, dan apa yang menjadi signifikan serta bermakna baginya (Harris, 2006). Prinsip yang terakhir adalah Commitment. Di dalam prinsip ini, individu diharapkan untuk dapat menyusun tujuan hidup dipandu oleh value yang dianggapnya penting kemudian ia mampu mengambil tindakan efektif untuk mencapainya (Harris, 2006).

Harris (2006) menyatakan bahwa teknik ini telah dianggap efektif dalam setting klinis sehingga telah sering diterapkan dalam berbagai kasus seperti depresi, OCD, stress di tempat kerja, chronic pain, kecemasan, PTSD, anoreksia, ketergantungan zat adiktif, bahkan pada kasus psikotik. Sebagaimana yang dijelaskan oleh Orsillo dan Batten (2005) bahwa Acceptance Commitment Therapy yang didesain untuk mengurangi experiential avoidance merupakan intervensi yang sesuai untuk individu yang mengalami PTSD. Penerapan intervensi tersebut dianggap terbukti sukses untuk membuat para penderita PTSD menerima pengalaman traumatis sehingga mereka mampu melanjutkan hidup yang lebih bermakna. Pernyataan tersebut didukung oleh penelitian Forman dkk (2005) bahwa Acceptance Commitment Therapy dianggap intervensi yang sukses dan efektivitasnya ekuivalen dengan terapi kognitif terhadap permasalahan kecemasan dan depresi. Lebih lanjut, Hayes dkk (2010) memaparkan bahwa Acceptance commitment therapy dianggap berguna sebagai tindakan preventif dan kuratif terhadap depresi yang dirasakan oleh para remaja. Rumusan masalah dalam penelitian ini adalah apakah penerapan acceptance commitment therapy dapat efektif dalam meningkatkan subjective well being pada individu dewasa muda pasca putusnya hubungan pacaran. Secara spesifik, permasalahan penelitian dirinci sebagai berikut:

a. Apakah penerapan acceptance commitment therapy dapat efektif dalam meningkatkan afek positif pada dewasa muda pasca putusnya hubungan pacaran?

b. Apakah penerapan acceptance commitment therapy dapat efektif dalam meningkatkan kepuasan hidup dewasa muda pasca putusnya hubungan pacaran?

c. Apakah distres emosional sebagai reaksi pasca putusnya hubungan pacaran dapat menurun setelah dewasa muda diberikan acceptance commitment therapy? 
d. Apakah perilaku obsesif dalam mengejar mantan pasangan sebagai reaksi pasca putusnya hubungan pacaran dapat menurun setelah dewasa muda diberikan acceptance commitment therapy?

\section{METODE}

Desain penelitian. Desain penelitian yang digunakan adalah one group pretest-posttest design. Desain tersebut sesuai dengan tujuan dari penelitian yakni untuk mengetahui efektivitas intervensi yang diberikan yaitu efektivitas Acceptance Commitment Therapy dalam meningkatkan subjective well being dewasa muda pasca putusnya hubungan pacaran. Pengukuran dilakukan baik secara kualitatif yakni dengan cara observasi dan wawancara; serta secara kuantitatif dengan menggunakan alat ukur berupa kuesioner. Dalam penelitian ini, peneliti melakukan pengukuran awal terhadap kondisi subjective well being yang dimiliki partisipan dan pengukuran kembali dilakukan setelah intervensi Acceptance Commitment Therapy selesai dilakukan sebagai bentuk manipulasi dengan menggunakan alat ukur yang sama. Dengan demikian pengaruh dari pemberian manipulasi yaitu Acceptance Commitment Therapy dapat dilihat dari perbedaan skor yang diperoleh melalui pretest dan posttest serta perbandingan keseluruhan data observasi dan wawancara.

Partisipan penelitian. Partisipan yang dipilih memiliki karakteristik sebagai berikut :

1. Individu yang tergolong kategori usia dewasa muda
2. Memiliki subjective well being yang rendah pasca putus hubungan pacaran. Hal tersebut ditunjukkan dengan rentang skor 1-3.9 pada Oxford Happiness Questionnaire dan rentang skor 18-51 pada Core Bereavement Item.

3. Berpendidikan minimal SMA.

4. Menyatakan bersedia mengikuti lima sesi intervensi dan dua kali pengukuran.

Teknik sampling. Peneliti menggunakan metode non-random sampling sebagai metode sampling yang digunakan dalam penelitian ini. Jenis non-random sampling yang digunakan dalam penelitian ini adalah purposive sampling, dimana pemilihan partisipan didasarkan pada tujuan penelitian sesuai dengan karakteristik atau kriteria yang sudah ditentukan (Kumar, 1999). Alat ukur yang digunakan dalam penelitian ini adalah kuesioner (Oxford Happiness Questionnaire dan Core Bereavement Item), Wawancara, dan Observasi. Berikut ini penjelasan mengenai tahapan dalam penelitian, yakni:

Tahap Persiapan. Peneliti melakukan sejumlah persiapan untuk melangsungkan penelitian mengenai acceptance commitment therapy pada individu dewasa muda pasca putus hubungan pacaran. Pertama, peneliti melakukan studi literatur dengan mencari, mengumpulkan, dan membaca fenomena, teori, serta hasil penelitian yang mengulas tentang teori terkait putusnya hubungan pacaran, subjective well being, dan intervensi menggunakan acceptance commitment therapy serta alat ukur untuk mengukur efektivitas 
intervensi. Kemudian, peneliti memulai proses pemilihan partisipan dengan cara menyebarkan informasi mengenai intervensi melalui media verbal, pesan tertulis seperti blackberry messenger, dan melalui jejaring sosial di dunia maya pada bulan Januari-Maret 2012. Setelah diperoleh sejumlah individu dewasa muda pasca putusnya hubungan pacaran, peneliti mulai melakukan proses screening dengan

Tahap Pelaksanaan Intervensi. Acceptance Commitment Therapy terhadap individu dewasa muda pasca putus hubungan pacaran memberikan pretest serta melakukan wawancara dan observasi pada minggu pertama bulan April 2012. Kemudian, peneliti menentukan sejumlah individu yang sesuai dengan karakteristik partisipan penelitian. Lalu, peneliti menghubungi calon partisipan yang memungkinkan untuk mengikuti program penelitian intervensi dan menanyakan kesediaan mereka.

berlangsung dalam 5 kali pertemuan, dengan perincian sebagai berikut:

Tabel 3.3 Rencana Pelaksanaan Intervensi

\begin{tabular}{|c|c|}
\hline Waktu Pertemuan & Rencana Kegiatan \\
\hline Sesi 1 & $\begin{array}{l}\text { - Diskusi mengenai fokus permasalahan dengan cara mengetahui } \\
\text { pikiran, emosi, sensasi, memori, dan strategi yang telah dilakukan oleh } \\
\text { partisipan selama ini dalam menghadapi permasalahan. } \\
\text { - Latihan teknik acceptance dengan melakukan observe, breath, dan } \\
\text { allow }\end{array}$ \\
\hline Sesi 2 & $\begin{array}{l}\text { - Diskusi mengenai pemikiran tidak berguna yang partisipan miliki } \\
\text { melalui tugas rumah daily pain experiences } \\
\text { - Latihan teknik cognitive defusion dengan melakukan milk,milk,milk } \\
\text { dan streaming on the river }\end{array}$ \\
\hline Sesi 3 & $\begin{array}{l}\text { - Latihan mindfulness dengan cara awareness of breath dan awareness } \\
\text { of eating. } \\
\text { - Praktek 'Mengamati diri' dengan cara mengingat kembali pengalaman- } \\
\text { pengalaman serta beberapa aspek penting dalam hidup seperti tubuh, } \\
\text { peran, emosi, dan pikiran. }\end{array}$ \\
\hline Sesi 4 & $\begin{array}{l}\text { - Pengisian Value Assesment Rating untuk mengetahui prioritas dalam } \\
\text { hidup partisipan. } \\
\text { - Diskusi mengenai tiga aspek kehidupan yang dianggap paling penting } \\
\text { oleh partisipan. }\end{array}$ \\
\hline Sesi 5 & $\begin{array}{l}\text { - Latihan membuat tujuan (immediate, jangka pendek, menengah, dan } \\
\text { panjang) kemudian mendiskusikannya. } \\
\text { - Diskusi mengenai FEAR dan ACT. }\end{array}$ \\
\hline
\end{tabular}




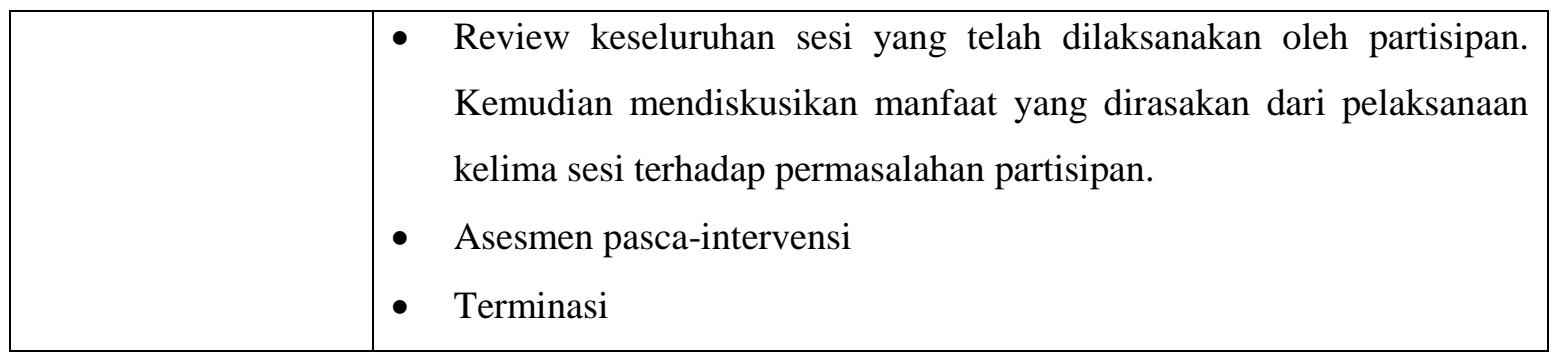

Dalam pelaksanaan intervensi, peneliti menggunakan acuan yang telah disusun berdasarkan teknik-teknik umum yang digunakan dalam acceptance commitment therapy secara umum (Harris, 2006). Intervensi dilakukan dengan durasi 90 menit untuk masing-masing sesi dan jarak antar pertemuan sekitar 1 minggu. Lebih lanjut, waktu dan tempat dari pelaksanaan penelitian akan disesuaikan dengan kesediaan partisipan. Hal ini mempertimbangkan kesibukan dari aktivitas partisipan itu sendiri.

Tahap Evaluasi. Evaluasi kuantitatif yang dilakukan dalam penelitian ini adalah dengan melihat ada atau tidaknya perubahan pada tingkat subjective well being yang dipersepsi oleh masing-masing pastisipan secara subjektif. Perubahan tersebut dapat diketahui melalui perbedaan nilai yang dipersepsi oleh partisipan pada meningkatnya skor OHQ (Oxford Happiness Questionnaire) dan menurunnya skor CBI (Core Bereavement Items) yang diisi oleh partisipan pada saat asesmen praintervensi dan pasca-intervensi. Selain itu, evaluasi kualitatif juga dilakukan dengan menggunakan metode wawancara dan observasi, dimana partisipan diharapkan dapat mengungkapkan ada atau tidaknya perubahan yang dirasakan oleh partisipan serta perubahan seperti apa yang dirasakan setelah mengikuti intervensi. Ditambah pula, partisipan diharapkan mengungkapkan sejauh mana harapan yang telah mereka buat di awal sesi terapi terwujud pada akhir sesi terapi. Dengan demikian, kontribusi dari keseluruhan program intervensi diharapkan dapat terlihat keefektivitasannya dalam membantu partisipan meningkatkan subjective well being.

HASIL

Tabel 4.1 Hasil Intervensi Partisipan 1 (Saski - Bukan Nama Sebenarnya)

\begin{tabular}{|l|l|l|}
\hline \multirow{2}{*}{} & \multicolumn{2}{|l|}{ Perbandingan Skor Kuantitatif } \\
\cline { 2 - 3 } & CBI & OHQ \\
\hline Pretest & 46 & 3.3 \\
\hline Posttest & 11 & 4 \\
\hline
\end{tabular}




\begin{tabular}{|c|c|c|}
\hline & \multicolumn{2}{|l|}{ Kesimpulan Observasi dan Wawancara } \\
\hline & Sebelum Intervensi & Selama Proses Intervensi \\
\hline Afek Positif & $\begin{array}{l}\text { Saski berusaha untuk bahagia dengan } \\
\text { cara bermain bersama teman-teman. } \\
\text { Ketika bersama teman atau keluarga, } \\
\text { Saski mampu merasa bahagia namun } \\
\text { ketika sendirian ia dengan mudahnya } \\
\text { merasa sedih kembali. }\end{array}$ & $\begin{array}{l}\text { Mulai sesi ketiga, Saski terlihat jauh } \\
\text { lebih tenang dan mampu banyak } \\
\text { tersenyum kepada peneliti. Ia pun } \\
\text { mengakui bahwa mulai sesi ketiga } \\
\text { tersebut dirinya merasa jauh lebih } \\
\text { bahagia dibandingkan beberapa bulan } \\
\text { sebelum ia mengikuti sesi terapi. }\end{array}$ \\
\hline $\begin{array}{l}\text { Kepuasan } \\
\text { Hidup }\end{array}$ & $\begin{array}{l}\text { Saski merasa hidupnya menjadi tidak } \\
\text { menyenangkan setelah diputuskan oleh } \\
\text { mantan pasangannya. Rutinitasnya } \\
\text { berubah secara total dan drastis sehingga } \\
\text { Saski merasa perlu beradaptasi dengan } \\
\text { perubahan ini. Belum lagi, ia merasa } \\
\text { semakin tua setiap harinya sehingga } \\
\text { merasa sulit dalam mencari pasangan } \\
\text { baru untuk menggantikan mantan } \\
\text { pasangannya tersebut. }\end{array}$ & $\begin{array}{l}\text { Pada dua sesi awal Saski merasa tidak } \\
\text { puas terhadap hidupnya karena } \\
\text { membandingkan dengan teman- } \\
\text { temannya yang memiliki pasangan. } \\
\text { Memasuki sesi ketiga, tidak ada lagi } \\
\text { penilaian seperti itu. Hingga pada sesi } \\
\text { kelima, Saski menunjukkan bahwa } \\
\text { dirinya sudah mampu menerima } \\
\text { putusnya hubungan pacaran dan } \\
\text { mengambil hikmah dari peristiwa } \\
\text { tersebut. Di sisi lain, Saski masih } \\
\text { belum merasa bahagia secara utuh } \\
\text { karena belum memperoleh pekerjaan } \\
\text { tetap yang baru. }\end{array}$ \\
\hline $\begin{array}{l}\text { Distres } \\
\text { emosional }\end{array}$ & $\begin{array}{l}\text { Saski sering teringat mantan } \\
\text { pasangannya dan mengalami mimpi } \\
\text { buruk. Hal tersebut membuat dirinya } \\
\text { sering merasa sedih hingga akhirnya } \\
\text { menangis tersedu-sedu dan merasa sesak. } \\
\text { Saski pun merasa marah, tidak terima, } \\
\text { dan bingung kenapa mantan pasangannya } \\
\text { memutuskannya lalu memilih perempuan } \\
\text { lain. Saski merasa dirinya tidak menjadi } \\
\text { lebih baik setelah diputuskan sehingga } \\
\text { tidak terlihat menarik. Ia merasa dirinya } \\
\text { yang bersalah atas perpisahan ini. }\end{array}$ & $\begin{array}{l}\text { Pada dua sesi awal, Saski masih } \\
\text { menunjukkan emosi marah dan sedih } \\
\text { yang intens setiapkali mengingat } \\
\text { mantannya. Pada sesi keempat dan } \\
\text { kelima, Saski masih menunjukkan } \\
\text { emosi sedih namun terkait dengan } \\
\text { masalah pekerjaan bukan karena } \\
\text { teringat mantan pasangannya. } \\
\text { Terkadang ia merasa khawatir akan } \\
\text { disakiti lagi jika menjalin hubungan } \\
\text { baru namun perasaan tersebut tidak } \\
\text { terlalu intens. }\end{array}$ \\
\hline
\end{tabular}




\begin{tabular}{|l|lll|l|}
\hline Perilaku & Saski berusaha mencari informasi & Pada dua sesi awal, Saski masih \\
mengejar & mengenai mantan pasangannya melalui & menunjukkan perilaku memata-matai \\
& jejaring sosial seperti twitter dan & mantan pasangannya dengan cara \\
facebook. Tak hanya melalui akun & melihat akun jejaring sosial pacar baru \\
mantan pasangannya melainkan juga & mantannya, menghubungi adik dari \\
melalui akun pasangan baru dari & mantannya, dan berusaha mencari \\
mantannya tersebut. Selain itu, Saski pun & sosok mantannya ketika melalui jalur \\
sesekali menanyakan kabar melalui & mantannya bekerja. Mulai dari sesi \\
teman atau anggota keluarga mantan & ketiga hingga kelima, Saski tidak lagi \\
pasangannya. ditambah pula, Saski sering \\
mencari sosok mantannya di jalur kerja \\
yang sering dilewati oleh mantannya \\
tersebut.
\end{tabular}

Tabel 4.2 Kesimpulan Hasil Intervensi Partisipan 2 (Leona - Bukan Nama Sebenarnya)

\begin{tabular}{|l|l|l|}
\hline \multirow{2}{*}{} & \multicolumn{2}{|l|}{ Perbandingan Skor Kuantitatif } \\
\cline { 2 - 3 } & CBI & OHQ \\
\hline Pretest & 38 & 3.5 \\
\hline Posttest & 16 & 4.5 \\
\hline
\end{tabular}

\begin{tabular}{|c|c|c|}
\hline & \multicolumn{2}{|l|}{ Kesimpulan Observasi dan Wawancara } \\
\hline & Sebelum Intervensi & Selama Proses Intervensi \\
\hline Afek Positif & $\begin{array}{l}\text { Leona merasa bahagia dengan } \\
\text { aktivitasnya sehari-hari karena ia sudah } \\
\text { mampu bekerja dan menghidupi dirinya } \\
\text { sendiri melalui bidang yang disukainya. } \\
\text { Selain itu, Leona mengakui bahwa dirinya } \\
\text { merasa senang dan bangga jika mantan } \\
\text { pasangannya masih berusaha untuk } \\
\text { menghubungi dan melakukan kontak } \\
\text { dengan dirinya. }\end{array}$ & $\begin{array}{l}\text { Dari lima sesi yang Leona ikuti, } \\
\text { dirinya menunjukkan ekspresi } \\
\text { bahagia ketika sesi dua dan sesi lima. } \\
\text { Pada sesi dua, Leona terlihat senang } \\
\text { karena mantannya memiliki ingatan } \\
\text { yang detail terhadap dirinya. } \\
\text { Sedangkan di sesi lima, Leona merasa } \\
\text { senang karena dirinya sudah mampu } \\
\text { bersikap tegas terhadap mantannya. }\end{array}$ \\
\hline $\begin{array}{l}\text { Kepuasan } \\
\text { Hidup }\end{array}$ & $\begin{array}{l}\text { Leona merasa keadaan tidak } \\
\text { menguntungkan dirinya terkait hubungan } \\
\text { romantisnya. Ia lebih sering menyalahkan } \\
\text { keadaan yang membuat dirinya harus }\end{array}$ & $\begin{array}{l}\text { Leona merasa cukup puas dengan } \\
\text { hidupnya karena ia memiliki banyak } \\
\text { aspek kehidupan yang mampu }\end{array}$ \\
\hline
\end{tabular}




\begin{tabular}{|c|c|c|}
\hline & $\begin{array}{l}\text { hidup berjauhan dengan mantan } \\
\text { pasangannya. ia pun merasa lelah } \\
\text { menjalani hidup dengan hubungan } \\
\text { romantis yang tidak jelas arahnya seperti } \\
\text { sekarang. }\end{array}$ & $\begin{array}{l}\text { memberikan kebahagiaan selain } \\
\text { mantan pasangannya. }\end{array}$ \\
\hline $\begin{array}{l}\text { Distres } \\
\text { emosional }\end{array}$ & $\begin{array}{l}\text { Leona merasa sedih, kecewa, dan marah } \\
\text { terhadap mantan pasangannya. Ia } \\
\text { berharap mantan pasangannya mampu } \\
\text { memberikan ketegasan terhadap } \\
\text { hubungan mereka kedepannya. Leona pun } \\
\text { merasa dirinya kurang diperjuangkan oleh } \\
\text { mantan pasangannya tersebut. }\end{array}$ & $\begin{array}{l}\text { Pada sesi-sesi sebelumnya, Leona } \\
\text { menunjukkan kesedihan dan } \\
\text { kekecewaan terhadap mantan } \\
\text { pasangannya. pada sesi terakhir, } \\
\text { emosi yang lebih kentara adalah } \\
\text { kekecewaan karena mantannya } \\
\text { belum mampu memberikan } \\
\text { ketegasan. }\end{array}$ \\
\hline $\begin{array}{l}\text { Perilaku } \\
\text { mengejar } \\
\text { mantan }\end{array}$ & $\begin{array}{l}\text { Leona jarang menghubungi mantannya } \\
\text { terlebih dahulu namun ia tidak dapat } \\
\text { menahan diri untuk menanggapi } \\
\text { mantannya tersebut. }\end{array}$ & $\begin{array}{l}\text { Leona sudah mampu memberikan } \\
\text { batasan yang tegas untuk tidak } \\
\text { menghubungi sama sekali dan } \\
\text { menanggapi mantannya tersebut. }\end{array}$ \\
\hline
\end{tabular}

Tabel 4.3 Kesimpulan Hasil Intervensi Partisipan 3 (Taasha - Bukan Nama Sebenarnya)

\begin{tabular}{|l|l|l|}
\hline \multirow{2}{*}{} & \multicolumn{2}{|l|}{ Perbandingan Skor Kuantitatif } \\
\cline { 2 - 3 } & CBI & OHQ \\
\hline Pretest & 30 & 3.1 \\
\hline Posttest & 10 & 4.7 \\
\hline
\end{tabular}

\begin{tabular}{|c|c|c|}
\hline & \multicolumn{2}{|l|}{ Kesimpulan Observasi dan Wawancara } \\
\hline & Sebelum Intervensi & Selama Proses Intervensi \\
\hline Afek Positif & $\begin{array}{l}\text { Taasha berusaha untuk bahagia dengan } \\
\text { cara bermain bersama teman-teman } \\
\text { kuliahnya atau menjalin hubungan } \\
\text { dengan pasangan yang baru. Akan tetapi, } \\
\text { kedua hal tersebut membuatnya } \\
\text { mengeluarkan energi yang besar dengan } \\
\text { hasil yang minimal karena masih tetap } \\
\text { memikirkan mantan pasangannya. }\end{array}$ & $\begin{array}{l}\text { Pada tiga sesi awal, ekspresi afektif } \\
\text { positif Taasha sangat minimal. Ia } \\
\text { hanya tersenyum sesekali dan } \\
\text { menunjukkan rasa terima kasih } \\
\text { kepada peneliti pada akhir sesi. Mulai } \\
\text { sesi keempat, Taasha menunjukkan } \\
\text { ekspresi bahagia selama sesi } \\
\text { berlangsung. Hingga pada sesi kelima, }\end{array}$ \\
\hline
\end{tabular}




\begin{tabular}{|c|c|c|}
\hline & & $\begin{array}{l}\text { ia menyatakan bahwa dirinya sudah } \\
\text { mampu mengikhlaskan semua } \\
\text { perilaku negatif yang dilakukan oleh } \\
\text { mantan pasangannya. }\end{array}$ \\
\hline $\begin{array}{l}\text { Kepuasan } \\
\text { Hidup }\end{array}$ & $\begin{array}{l}\text { Taasha merasa tidak terima dan tidak } \\
\text { puas dengan kehidupan masa lalunya. Ia } \\
\text { merasa hubungannya dengan mantan } \\
\text { pasangannya telah membuatnya rugi } \\
\text { secara materi dan emosi serta kekerasan } \\
\text { fisik. Ia pun merasa ditinggalkan serta } \\
\text { kurang diperjuangkan oleh mantan } \\
\text { pasangannya tersebut. }\end{array}$ & $\begin{array}{l}\text { Taasha merasa hidupnya jauh lebih } \\
\text { bahagia setelah putus dan menjalin } \\
\text { hubungan yang baru. Ia merasa jauh } \\
\text { lebih dianggap, dan diperhatikan. Ia } \\
\text { pun mampu melakukan apa yang ia } \\
\text { sukai secara bebas. }\end{array}$ \\
\hline $\begin{array}{l}\text { Distres } \\
\text { emosional }\end{array}$ & $\begin{array}{l}\text { Taasha merasa sedih, kecewa, dan marah } \\
\text { terhadap mantan pasangannya. Ia } \\
\text { berharap mantan pasangannya tidak } \\
\text { memutuskan kontak komunikasi karena } \\
\text { ia masih ingin menjalin hubungan } \\
\text { pertemanan seperti dulu. }\end{array}$ & $\begin{array}{l}\text { Pada tiga sesi awal, Taasha masih } \\
\text { merasa marah dan menunjukkan } \\
\text { perasaan sedih. Mulai sesi keempat } \\
\text { hingga sesi kelima, Taasha tidak lagi } \\
\text { menunjukkan afek negatif terhadap } \\
\text { mantan pasangannya. }\end{array}$ \\
\hline $\begin{array}{l}\text { Perilaku } \\
\text { mengejar } \\
\text { mantan }\end{array}$ & $\begin{array}{l}\text { Taasha berusaha memperoleh informasi } \\
\text { mengenai mantan pasangannya melalui } \\
\text { teman atau keluarga lelaki tersebut. } \\
\text { Selain itu, ia pun memata-matai akun } \\
\text { jejaring sosial milik mantannya tersebut. }\end{array}$ & $\begin{array}{l}\text { Pada tiga sesi awal, Taasha masih } \\
\text { menunjukkan usaha dengan cara } \\
\text { mengecek akun media sosial milik } \\
\text { mantannya atau menghubungi teman } \\
\text { dan adik mantannya. Mulai sesi } \\
\text { keempat, Taasha tidak menunjukkan } \\
\text { usaha apapun lagi untuk mengontak } \\
\text { mantannya. }\end{array}$ \\
\hline
\end{tabular}

\section{SIMPULAN}

Berdasarkan pelaksanaan intervensi dan diskusi dapat disimpulkan bahwa: Penerapan Acceptance Commitment Therapy dapat efektif dalam meningkatkan subjective well being pada individu dewasa muda pasca putusnya hubungan pacaran. Afek positif dan kepuasan hidup terbukti meningkat setelah intervensi diberikan pada individu dewasa muda pasca putusnya hubungan pacaran. Selain itu, distres emosional dan perilaku obsesif dalam mengejar mantan sebagai reaksi pasca putusnya hubungan pacaran dapat menurun setelah individu dewasa muda pasca putusnya hubungan pacaran diberikan acceptance commitment therapy. 
Terkait saran metodologis, peneliti menyarankan agar penelitian kedepannya melakukan penelitian mengenai acceptance commitment therapy bagi dewasa muda pasca putusnya hubungan pacaran dengan metode quasi eksperimental desain dua kelompok untuk menilai efektivitas intervensi ini jika dibandingkan dengan intervensi lain. Dua kelompok yang dimaksud berupa kelompok yang mendapatkan acceptance commitment therapy dan kelompok kontrol yang hanya diberikan konseling, dalam periode waktu yang sama. Selain itu, diharapkan penelitian selanjutnya melakukan uji validitas dan realibilitas terhadap alat ukur subjective well being yang digunakan sehingga diperoleh cutoff score yang telah disesuaikan dengan budaya. Terakhir, peneliti menyarankan untuk menggunakan kuesioner yang dapat mengukur kepribadian seperti pola kelekatan individu, tingkat self esteem, atau tingkat sensitivitas terhadap penolakan agar mampu menggambarkan faktor yang mempengaruhi partisipan dengan lebih komprehensif.

Terkait saran praktis untuk penelitian selanjutnya, diharapkan agar pemberian

\section{DISKUSI}

Berdasarkan hasil yang diperoleh, ketiga partisipan menunjukkan adanya perubahan baik secara kuantitatif maupun kualitatif dalam tingkat subjective well being setelah diberikan intervensi. Secara kuantitatif, Taasha menunjukkan skor OHQ paling tinggi yakni 4.7 dan skor CBI paling rendah yakni 10. Oleh karena itu, jika dibandingkan dengan dua partisipan lainnya, Taasha yang metafora dalam sesi intervensi dapat disesuaikan dengan konteks budaya Indonesia agar partisipan mampu lebih memahami makna dari metafora tersebut. Selain itu, peneliti dan partisipan melakukan kesepakatan agar partisipan mengimplementasikan latihanlatihan praktek yang telah diajarkan dalam seluruh rangkaian sesi secara konstan saat harus menghadapi kondisi-kondisi tidak menyenangkan dalam kehidupan sehari-hari. Lebih jauh, sebaiknya ada penambahan sesi follow up yang dilakukan sekitar 4 minggu setelah terminasi untuk mengetahui penghayatan dan cara partisipan mempertahankan subjective well being meskipun tidak lagi didampingi oleh peneliti. Terakhir, peneliti sebaiknya memberikan informasi terhadap significant others, agar mereka memberikan dukungan sosial kepada partisipan. Diharapkan dukungan sosial tersebut dapat membantu partisipan untuk meningkatkan dan mempertahankan tingkat kebahagiaan atau subjective well being yang mereka miliki.

menunjukkan tingkat subjective well being paling tinggi. Jika dikaitkan dengan salah satu faktor yang mempengaruhi subjective well being yakni status pernikahan, meskipun ketiga-tiganya belum menikah, Taasha adalah partisipan yang telah memiliki pasangan tetap sedangkan dua partisipan lainnya berstatus lajang. Seperti penjelasan Lynette-Krech (2008), individu yang telah menikah lebih 
merasa bahagia dibandingkan dengan yang belum menikah, sedangkan individu yang telah memiliki pasangan lebih merasa bahagia dibandingkan mereka yang berstatus lajang.

Di sisi lain, Saski menunjukkan penurunan skor CBI yang tajam yakni dari 46 menjadi 11. Sedangkan, skor OHQ miliknya hanya berubah dari 3.3 menjadi 4. Dapat diinterpretasikan bahwa tingkat perasaan berduka yang dialami Saski sudah menurun drastis setelah pemberian intervensi. Dirinya sudah tidak lagi memiliki ruminasi terhadap mantan pasangannya, sudah mampu menerima perpisahan, dan tidak lagi bersedih atas putusnya hubungan romantis dengan pasangannya. Akan tetapi, Saski belum dapat merasa bahagia secara utuh, kadar subjective well being hanya berada pada tingkat satisfied. Tepat di minggu keempat pemberian intervensi, Saski harus menerima kenyataan bahwa kantornya ditutup sehingga ia dan karyawan lainnya kehilangan pekerjaan. Jika dikaitkan dengan faktor yang mempengaruhi tingkat subjective well being seseorang, pekerjaan adalah salah satu faktor yang mempengaruhi . seperti pemaparan Argyle dalam Carr (2004) yakni status pekerjaan berhubungan dengan kebahagiaan dimana orang yang bekerja cenderung lebih bahagia dibandingkan orang yang tidak bekerja.

Di sisi lain, Leona menunjukkan skor CBI yang paling tinggi dibandingkan kedua partisipan lainnya yakni sebesar 16, meskipun ketiganya sama-sama tergolong pada kategori rendah. Tampaknya hal ini berkaitan dengan komunikasi dengan mantan pasangan yang masih intens dilakukan oleh Leona, sedangkan kedua partisipan lainnya tidak lagi memiliki akses komunikasi dengan mantan pasangannya. tak hanya komunikasi seperti berbincang di telepon dan saling berkiriman pesan singkat, Leona pun masih melakukan cyber sex melalui video chat dengan mantan pasangannya hingga pemberian intervensi di minggu keempat. Oleh karena itu, tingkat ruminasi terhadap mantan pasangannya dan tingkat kesedihan yang dirasakan Leona masih jauh lebih tinggi dibandingkan partisipan lainnya. Sedangkan, skor OHQ Leona menunjukkan angka 4.5 yang dapat diinterpretasikan bahwa ia cukup merasa bahagia dengan hidupnya. Jika dikaitkan dengan faktor yang mempengaruhi tingkat subjective well being, Leona merasa dirinya puas karena mampu menyelesaikan pendidikan S1 tepat pada waktunya dan sekarang memiliki pekerjaan sesuai dengan bidang yang diminatinya yakni anak-anak berkebutuhan khusus.

Terkait dengan reaksi distres emosional, Saski menunjukkan kesedihan yang intens baik di luar maupun di dalam ruang terapi. Terlihat ia beberapa kali menangis hingga tersedu-sedu dan sulit melanjutkan kata-katanya ketika berbicara dengan peneliti. Tampaknya hal ini berkaitan dengan inisiator putusnya hubungan pacaran mereka, berbeda dengan dua partisipan yang lain, Saski menjadi pihak yang diputuskan oleh pasangannya. Secara teoretis, status inisiator menunjukkan bahwa individu yang diputuskan biasanya merasa jauh lebih sulit untuk menerima dampak dari pemutusan hubungan sebagai peristiwa yang tidak ia harapkan (Sprecher, 1994). Sesuai dengan pernyataan tersebut, selama dua sesi awal, 
Saski menyatakan dirinya tidak terima karena pasangannya telah tega memutuskan hubungan mereka bahkan telah menjalin hubungan dengan perempuan lain. Saski pun mengeluhkan kekhawatirannya terkait memperoleh pasangan yang baru. Periloux \& Buss (2008) menjelaskan bahwa pihak yang diputuskan melaporkan pengalaman depresi yang lebih banyak disertai dengan ruminasi yang lebih sering, ditambah dengan pengurangan self esteem, serta mempersepsikan diri sebagai individu yang kurang diinginkan, dan merasa lebih khawatir bahwa mereka akan kesulitan untuk menemukan pasangan yang baru.

Lebih lanjut, tak hanya Saski yang menunjukkan distres emosional dalam bentuk kesedihan, kedua partisipan yang lain pun menunjukkan hal yang sama. Leona menunjukkan kekecewaan yang lebih besar sedangkan Taasha menunjukkan rasa marah dan dendam yang lebih besar. Seperti yang dijelaskan oleh Sprecher (1994) tentunya tidak mengejutkan jika seorang individu merasa marah, terluka, frustasi, dendam, kesepian, dan depresi setelah melewati putusnya hubungan pacaran. Jika dikaitkan dengan durasi berpacaran, ketiga partisipan telah menjalani hubungan yang lama dengan mantan pasangannya, sehingga afek negatif yang dirasakan ketika putusnya hubungan tersebut semakin besar. Sesuai dengan hal itu, Park \& Sanchez (2007) menyatakan bahwa semakin lama seseorang menjalin sebuah hubungan maka semakin banyak investasi emosi yang mereka simpan terhadap hubungan tersebut sehingga semakin sulit ketika mereka harus berpisah.
Terkait perilaku obsesif mengejar mantan, Park \& Sanchez (2007) menjelaskan bahwa fenomena internet yang mempermudah seseorang untuk mengakses informasi orang lain membuat pasangan yang telah putus mengalami ruminasi yang lebih sulit untuk diminimalisasikan. Mereka berusaha untuk tetap memperoleh informasi mengenai mantan pasangan melalui akun jejaring sosial milik mantan pasangannya. Hal tersebut dialami oleh ketiga partisipan, mereka berushaa untuk tetap memperoleh informasi mengenai mantan pasangannya melalui internet yakni mengakses akun jejaring sosial milik mantan pasangan atau pasangan baru dari mantan pasangannya. Selain itu, Saski melakukan perilaku memata-matai karena dirinya adalah pihak yang diputuskan. Seperti penjelasan Davis dkk (2007) Perilaku memata-matai tergolong dalam perilaku obsesif mengejar mantan pasangan karena merepresentasikan usaha untuk memperoleh kontrol kembali dari mantan pasangan, oleh karena itu, pihak yang ditinggalkan cenderung akan memata-matai mantan pasangannya dibandingkan pihak yang menjadi inisiator putus. Di sisi lain, Leona dan Taasha bertindak sebagai inisiator putus akan tetapi mereka pun melakukan perilaku mengejar seperti menghubungi mantan pasangan terlebih dahulu atau mengecek akun jejaring sosial milik mantan karena terjadi pola Velcro dalam hubungan mereka.

Pada kasus Leona, ia terjebak dalam hubungan tanpa status dengan mantan pasangannya. Meskipun mereka telah putus semenjak 3 tahun yang lalu, pada akhirnya mereka tetap saling menghubungi satu sama lain. Pola seperti ini telah terjadi selama mereka 
menjalin hubungan selama 8 tahun, mereka seringkali putus namun pada akhirnya memutuskan untuk kembali bersama. Pola hubungan tersebut tampaknya dapat dijelaskan dengan pola 'Velcro', dimana pola tersebut menjelaskan mengenai seberapa banyak atau sering pasangan namun akhirnya mereka kembali bersatu (Davis dkk, 2007). Hal yang serupa terjadi pada Taasha, dimana hubungannya dengan mantan pasangannya telah terjalin selama 6 tahun 6 bulan, selama itu mereka pun seringkali putus namun pada akhirnya memutuskan untuk kembali bersama. Secara teoretis, pola ini hubungan seperti ini menghasilkan pandangan bahwa jika salah satu pihak berjuang dengan lebih keras maka mereka akan dapat menjalin hubungan kembali (Westrup, 1998). Teori tersebut sesuai dengan pernyataan Leona bahwa dirinya berharap mantan pasangannya mampu memperjuangkan hubungan mereka sehingga mereka dapat bersatu kembali. Bahkan Taasha yang telah memiliki pasangan baru, sempat menyatakan bahwa dirinya akan lebih memilih mantan pasangannya jika saja lelaki tersebut menunjukkan usaha perjuangan yang lebih untuk kembali menyatukan hubungan mereka.

\section{Lebih lanjut, Schneller (2003)} menyatakan bahwa hilangnya suatu hubungan dapat mempengaruhi perasaan seseorang mengenai dirinya sendiri, seperti contohnya seseorang memiliki preokupasi terhadap keinginan untuk melakukan rekonsiliasi sehingga orang tersebut tidak mampu menginvestasikan energinya secara simultan dalam membangun hubungan alternatif lainnya. Oleh karena itu, ketiga partisipan sulit menjalin hubungan baru dengan orang lain.
Saski memiliki kekhawatiran akan disakiti kembali atau memperoleh penolakan jika ia membuka hatinya untuk orang yang baru. Sedangkan Leona selalu berakhir dengan membanding-bandingkan lelaki yang mendekatinya dan mantan pasangannya. Di sisi lain, meskipun Taasha sudah mampu berhasil menjalin hubungan baru, terkadang ia masih memikirkan mantan pasangannya dan memiliki kekhawatiran terhadap pasangannya yang baru.

Terkait dengan perilaku seksual, peneliti tidak menanyakan hal tersebut secara langsung kepada ketiga partisipan. Hanya partisipan kedua yakni Leona yang mengaku bahwa dirinya telah melakukan cyber sex dengan mantan pasangannya dalam beberapa bulan terakhir ini. Seperti yang telah dipaparkan oleh Miller \& Perlman (2009), kontak fisik secara seksual meningkatkan kelekatan emosi yang dirasakan oleh pasangan, terutama pada wanita dibandingkan laki-laki. Hal ini yang tampaknya membuat Leona jauh lebih sulit untuk melupakan mantan pasangannya dan masih berharap dapat memperbaiki hubungan mereka seperti sedia kala. Di sisi lain, kedua partisipan yang lain melaporkan bahwa aktivitas seksual mereka dengan mantan pasangannya hanya sebatas pelukan dan ciuman pipi serta bibir.

Terkait aspek kepuasan hidup, Saski dan Taasha mampu mengambil hikmah positif atas perpisahan dengan mantan pasangan mereka karena mereka merasa telah mengabaikan banyak value penting dalam hidup mereka saat berpacaran dengannya. Justru mereka mampu berperilaku dengan lebih bebas dan membuat keputusan yang sesuai dengan keinginan setelah berpisah dengan 
mantan pasangannya. Seperti penjelasan, Diener, Scollon, \& Lucas (2003) bahwa individu membandingkan domain dengan rentang waktu, individu pun menelaah berbagai domain dalam kehidupannya (keluarga, pekerjaan, hubungan romantis, persahabatan, kehidupan komunitas, dan lain-lain), kemudian menimbang pentingnya domain tersebut sehingga ia mampu mengumpulkan sejumlah penilaian lengkap untuk memperoleh keseluruhan evaluasi terhadap kepuasan hidupnya. Sedangkan pada kasus Leona, ia mampu merasa puas dengan hidupnya karena melihat berbagai pencapaian yang telah ia peroleh pada bidang akademis dan non akademis. Ia merasa bahwa dirinya memiliki banyak aspek lain yang mampu membuat bahagia. Sesuai dengan penjelasan Campbell dkk dalam Diener, Scollon, \& Lucas, (2003) yakni individu melihat domain yang penting dalam hidup dan membandingkan domain kehidupan tersebut dengan berbagai standar pembanding misalnya situasi yang mereka alami di masa lalu, keadaan lingkungan sekitar mereka masa kini, ataupun harapan akan sesuatu di masa depan.

Pada akhirnya, ketiga partisipan menunjukkan perubahan pada aspek distres emosional, perilaku mengejar mantan, dan kepuasan hidup setelah diberikan intervensi acceptance commitment therapy. Meskipun ACT bertujuan untuk menciptakan kehidupan yang lebih bermakna dan fleksibilitas psikologis bukannya mereduksi simtom, secara tidak langsung simptom tersebut akhirnya tereduksi. Selama intervensi, peneliti mampu menjalankan sesi sesuai dengan rancangan sesi yang telah dibuat sebelumnya tanpa mengalami hambatan yang signifikan. Partisipan mampu mengikuti latihan praktek dan memahami makna dari setiap latihan tersebut sesuai dengan harapan. Akan tetapi, metafora yang diberikan tampaknya membingungkan partisipan terutama dalam mengaitkannya dengan permasalahan yang sedang dirasakan. Tampaknya hal tersebut terjadi karena metafora yang diberikan kurang sesuai dengan konteks budaya Indonesia dan kehidupan mereka sehari-hari.

Pada prinsip acceptance, ketiga partisipan diharapkan dapat menerima peristiwa putusnya hubungan romantis mereka dan tetap melanjutkan hidup yang bermakna. Saski terlihat sudah menunjukkan penerimaan terhadap status lajangnya meskipun ia tidak pernah mengalami proses lajang selama ini. Ia pun telah menerima bahwa mantan pasangannya sudah tidak lagi mencintainya dan memilih pasangan yang baru. Sedangkan Leona menunjukkan bahwa dirinya telah berusaha menerima bahwa selama ini pasangannya tidak mampu memberikan ketegasan terhadap hubungan mereka berdua. Sedangkan Taasha telah berusaha menerima bahwa saat ini ia tidak lagi dapat berkomunikasi dan menjalin hubungan pertemanan dengan mantan pasangannya sama sekali.

Pada prinsip cognitive defusion, ketiga partisipan menunjukkan bahwa mereka berusaha menerima setiap hal yang muncul dalam pemikirannya, baik perkataan negatif, gambar yang mengingatkan masa lalu, atau kenangan yang menyakitkan. Mereka yakin bahwa setiap pemikiran yang muncul pada akhirnya akan hilang juga, oleh karena itu pemikiran yang tidak berguna tidak boleh 
dijadikan sebagai penghambat dalam menjalani hidup yang bermakna. Pada prinsip mindfulness, ketiga partisipan menunjukkan bahwa mereka menyadari bahwa selama ini telah membiarkan diri mereka hidup di masa lalu dan terlalu mencemaskan masa depan sehingga mereka tidak fokus terhadap apa yang mereka sedang jalani saat ini. Oleh karena itu, mereka menyatakan bahwa akan berusaha untuk tetap menghargai masa kini dengan cara memberikan fokus perhatian dan kesadaran mereka pada apa yang sedang dilakukan dibandingkan memikirkan mantan pasangannya.

Pada prinsip observing self, ketiga partisipan menunjukkan bahwa latihan tersebut menyadarkan mereka akan hidup yang telah dijalani selama ini. Mereka sadar bahwa mereka terus tumbuh dan ada banyak hal yang berubah selama proses pertumbuhan tersebut. Tidak ada yang konstan di dalam hidup mereka oleh karena itu mereka harus yakin bahwa peristiwa putusnya hubungan yang menyakitkan ini pun nantinya tidak lagi mampu menyakiti mereka. Sedangkan terkait prinsip values, Saski dan Taasha menyadari bahwa hubungan mereka dengan mantan pasangan telah membuat mereka mengabaikan valuevalue penting dalam hidup mereka. Oleh karena itu, mereka menjadi dapat mengambil hikmah positif dari putusnya hubungan mereka dengan mantan pasangan. Di sisi lain, sesi values membuat Leona menyadari bahwa ada banyak hal penting dalam kehidupannya yang mampu membuatnya jauh lebih bahagia dibandingkan mantan pasangannya. oleh karena itu, tak seharusnya ia terlarut dalam perasaan sedih karena tak kunjung memperoleh kejelasan hubungan dari mantan pasangannya. Leona akan berusaha mencari kebahagiaan melalui kontribusi yang dapat ia berikan terhadap masyarakat karena itulah hal penting di dalam hidupnya.

Terkait prinsip commitment yang menjadi sesi terakhir, ketiga partisipan menunjukkan bahwa mereka telah mampu menyusun tujuan yang sesuai dengan value penting di dalam hidupnya. Meskipun mereka memiliki kekhawatiran apakah dirinya mampu mencapai tujuan tersebut, mereka menyatakan bahwa tidak akan membiarkan perasaan negatif menghambat dalam proses pencapaian tujuan mereka. Artinya, mereka sudah mampu memahami konsep willingness dimana seseorang akan terus berusaha menjaga komitmen untuk mencapai tujuannya meskipun ada hal menyakitkan dan perasaan negatif yang muncul pada saat proses pencapaian tujuan tersebut.

Kesimpulannya, keenam prinsip dari acceptance commitment therapy telah berhasil meningkatkan fleksibilitas psikologis dari ketiga partisipan. Mereka telah berhasil kembali memahami apa yang paling penting di dalam hidup, menerima setiap peristiwa dan pengalaman yang menyakitkan, dan berusaha melakiukan tindakan efektif agar tercapainya kehidupan yang bermakna. Pada akhirnya, prinsip dari acceptance commitment therapy efektif dalam membantu mereka meningkatkan subjective well being atau kebahagiaan pasca putusnya hubungan pacaran mereka.

Penelitian ini memperkaya khazanah penelitian di Indonesia terutama mengenai intervensi psikologis terhadap individu dewasa muda yang mengalami penurunan subjective 
well being pasca putus hubungan pacaran. Penelitian ini memberikan gambaran mengenai salah satu alternatif implementasi penanganan bagi para psikolog dalam meningkatkan subjective well being individu dewasa muda

\section{DAFTAR PUSTAKA}

Berscheid, E., \& Reis, H. T. (1998). Attraction and close relationships. In D. T. Gilbert, S. T. Fiske, \& G. Lindzey (Eds.), The handbook of social psychology (pp. 193281). New York, NY, US: McGraw-Hill. Cupach, W. (2003). What Mad Pursuit? . Aggression and Violent Behaviour, 8, 345-375.

Carr, A. (2004). Positive Psychology : The Science of Happiness and Human Strengths. Hove \& NewYork : Brunner Routledge Taylor\& Francis Group.

Davis, K.E., dkk. (2007). Stalking Perpetrators and Psychological Maltreatment of Partner. Personal Relationship, 77, 1-45.

Diener, E., Scollon, E., \& Lucas, R. (2003). Subjective Well Being: Three decades of progress. Psychological Bulletin, 125, 276-302.

Docherty, Gavin. (2007). The Effects of Romantic Dissolution on Well Being. Psychological Bulletin, 127, 276-312

Feist, J. and Feist, G. (2009). Theories of personality. Boston: McGraw Hill Higher Education.

Fledderus, M. (2012). Efficacy of an Early Intervention Based on Acceptance and pasca putusnya hubungan pacaran melalui Acceptance Commitment Therapy.

Commitment Therapy for Adults with Depressive Symptomatology. Behaviour Research and Therapy, 49, 62-67.

Forman, E.M., dkk. (2005). A Randomized Controlled Effectiveness Trial of Acceptance and Commitment Therapy and Cognitive Therapy for Anxiety and Depression. Behaviour Modification, 47, $1-28$.

Harris, R. (2006). Embracing Your Demons: an Overview of Acceptance and Commitment Therapy. Psychotherapy in Australia, 12, 4.

Hayes, S.C., dkk. (2010). Acceptance and Commitment Therapy: Model, processes and outcomes. Behaviour Research and Therapy, 44, 1-25.

Kumar, R. (1999). Research Methodology: A Step by Step Guide for Beginners. Australia: Pearson Education.

Kiecolt-Glaser, JK. (2001) Marriage and health: his and hers. Psychology Bulletin, 2001 Jul; 127(4):472-503.

Honeycutt, J.M., Cantrill, J.G. (2000). Cognition, Communication, and Romantic Relationship. Routledge: New York. 
Lynette-Krech, A., dkk. (2008). Romantic Relationship and Happiness. Personal Relationship, 18, pg 380-393.

Lyubormrsky,S.

Sheldon,K.M.2005.Pursuiting

Happiness:The Architecture Of

Sustainable Change.Review Of General Psychology,2,11-131.

Mearns, J. (1991). Coping with a breakup: Negative mood regulation expectancies and depression following the end of a romantic relationship. Journal of Personality and Social Psychology, 60(2), 327-334.

Miller, R. S., Perlman, D. (2009). Intimate Relationships (5 th ed.). New York :McGraw-Hill.

Nolen-Hoeksema, S., Girgus, J.S. (1994). The emergence of gender differences in depression during adolescence. Psychological Bulletin, 115(3):424-43.

Orsillo, S.M., \& Batten, S.V. (2005). Acceptance and Commitment Therapy in the Treatment of Posttraumatic Stress Disorder. Behaviour Modification, 29 (1), pg 95-129.

Park, L.E., \& Sanchez, D.T. (2007). Maladaptive Responses to Relationship Dissolution: The Role of Relationship Contingent Self-Worth. Journal of Applied Social Psychology,12, pg 1-43.

Perilloux, C., \& Buss, D.M. (2008). Breaking Up Romantic Relationships: Costs
Experienced and Coping Strategies Deployed. Evolutionary Psychology, 6(1), 164-178.

Reis, H., Collins,W.A., Berscheid, E. (2000). The Relationship Context of Human Behavior and Development. Psychological Bulletin, 126(6):844-72

Schneller, D. P. (2003). After the breakup: Adult perceptions and expectations of post-divorce intimate relationships. Dissertation Abstracts International, 63(8-A). 3017, US: Univ Microfilms International Abstract, March 2003.

Sprecher, S. (1994). Two Sides to the breakup of romantic relationships. Personal Relationship, 1, 199-222.

Theuns, P., dkk. (2010). An Experimental Approach to the Joint Effects of Relations with Partner, Friends, and Parents on Happiness. Psicologica, 31, pg 629-645.

Torges C, Stewart A, Nolen-Hoeksema S. Regret resolution, aging, and adapting to loss. (2008). Psychology and Aging. 23(1):169-180.

Van IJzendoorn, M. H., \& BakermansKranenburg, M. J. (1997). Intergenerational transmission of attachment: A move to the contextual level. In L. Atkinson \& K. J. Zucker (Eds.), Attachment and psychopathology (pp. 135-170). New York, NY, US: Guilford Press. 
Westrup, D. (1998). Applying functional analysis to stalking behavior. The Psychology of Stalking Clinical and Forensic Perspective. NY: Academic press. 